\title{
Physicochemical and sensory properties of papaya fruits of elite lines and hybrids
}

\section{Características físico-químicas e sensoriais de frutos de híbridos e linhagens elites de mamoeiro}

\author{
Eline de Moura Luz Carvalho'; Ronielli Cardoso Reis ${ }^{2 *}$; Viviane Peixoto Borges ${ }^{3}$; \\ Carlos Alberto da Silva Ledo²; Eliane da Silva Araújo ${ }^{4}$; Jorge Luiz Loyola Dantas ${ }^{5}$
}

\begin{abstract}
This study aimed to evaluate papaya elite lines and hybrids as to fruit physicochemical and sensory characteristics, thus identifying the most promising ones for the market. Fruits from improved genotypes of the Solo group (CMF H10.60, CMF L78, and UC 14) and Formosa group (CMF L10, UC 10, and UC 12) were evaluated, and the commercial cultivars Golden and Tainung $\mathrm{n}^{\circ} 1$ were used as controls. The following physical and physicochemical evaluations were performed: fruit length and diameter, fruit inner cavity diameter, fruit weight, fruit and pulp firmness, soluble solids, $\mathrm{pH}$, titratable acidity, Ratio (soluble solids and titratable acidit relation), and firmness of peeled and unpeeled ripe fruits. Sensory tests were performed with 50 papaya consumers. In general, the improved genotypes of the Solo and Formosa groups showed similar physical and physicochemical characteristics to the Golden and Tainung $\mathrm{n}^{\circ} 1$ controls. The CMF L78 line of the Solo group and the UC10 hybrid of the Formosa group showed similar fruit firmness and ratio characteristics compared to both commercial cultivars. The three new genotypes in the Solo group showed superior sensory characteristics to the commercial cultivar Golden. The internal preference mapping of this group revealed a higher preference for the genotypes UC 14 and CMF L78, for having fruits with more intense color, stronger flavor, and firmer texture than the others. In the Formosa group, the UC 10 genotype outperformed the cultivar Tainung $\mathrm{n}^{\mathrm{o}} 1$, with a global acceptance percentage of $96.15 \%$, due to a more intense aroma, color, and flavor. The CMF L78 line of the Solo group and the UC 10 hybrid of the Formosa group have excellent physicochemical and sensory characteristics and are therefore promising alternatives to replace both commercial cultivars (Golden and Tainung $\mathrm{n}^{\circ} 1$ ).
\end{abstract}

Key words: Carica papaya L. Genetic breeding. Preference mapping. Sensory acceptance.

\section{Resumo}

O objetivo deste trabalho foi avaliar linhagens e híbridos elites de mamoeiro quanto às características físico-químicas e sensoriais de frutos, visando identificar os mais promissores para o mercado. Foram

1 M.e em Ciências Agrárias, Universidade Federal do Recôncavo da Bahia, UFRB, Cruz das Almas, BA, Brasil. E-mail: elinemluz@hotmail.com

2 Pesquisadores, Empresa Brasileira de Pesquisa Agropecuária, EMBRAPA Mandioca e Fruticultura, CNPMF, Cruz das Almas, BA, Brasil. E-mail: ronielli.reis@embrapa.br; carlos.ledo@embrapa.br

3 Pós-Doutoranda, UFRB, Centro de Ciências Agrárias, Ambientais e Biológicas CCAAB, Cruz das Almas, BA, Brasil. E-mail: vivipborges@yahoo.com.br

4 Discente do Curso de Graduação em Agronomia, UFRB, Cruz das Almas, BA, Brasil. E-mail: araujollia@hotmail.com

5 Pesquisador Aposentado, EMBRAPA Mandioca e Fruticultura, CNPMF, Cruz das Almas, BA, Brasil; Prof., Faculdade Maria Milza, FAMAM, Cruz das Almas, BA, Brasil. E-mail: jorge.loyola@famam.com.br

* Author for correspondence 
avaliados frutos de genótipos melhorados do grupo Solo (CMF H10.60, CMF L78, UC 14) e do grupo Formosa (CMF L10, UC 10, UC 12), e como testemunhas as variedades comerciais Golden e Tainung ${ }^{\circ}$ 1. Foram realizadas as seguintes avaliações físicas e físico-químicas: comprimento e diâmetro do fruto, diâmetro da cavidade interna dos frutos, peso do fruto, firmeza do fruto e da polpa, sólidos solúveis, $\mathrm{pH}$, acidez titulável Ratio (razão entre sólidos solúveis e acidez titulável) e firmeza dos frutos maduros com casca e sem a casca. Os testes sensoriais foram realizados com 50 consumidores de mamão. De uma forma geral, os genótipos melhorados do grupo Solo e Formosa apresentaram características físicas e físico-químicas semelhantes às testemunhas Golden e Tainung $n^{\circ} 1$. A linhagem CMF L78, do grupo Solo, e o híbrido UC10, do grupo Formosa, apresentaram características de firmeza de fruto e Ratio semelhantes às cultivares comerciais Golden e Tainung $n^{\circ} 1$. Em relação às características sensoriais dos genótipos do grupo Solo, os três novos genótipos superaram a cultivar comercial Golden. O mapa de preferência interno desse grupo revelou uma maior preferência para os genótipos UC 14 e CMF L78, que foram considerados frutos com cor mais intensa, sabor mais forte e textura mais firme que os demais. No grupo Formosa, o genótipo UC 10 superou a cultivar Tainung $\mathrm{n}^{\circ} 1$, com percentual de aceitação global $96,15 \%$ e foi considerado com aroma, cor e sabor mais intensos. A linhagem CMF L78, do grupo Solo, e o híbrido UC 10, do grupo Formosa, apresentam excelentes características físicoquímicas e sensoriais e, portanto, são alternativas promissoras para substituir as cultivares comerciais Golden e Tainung $n^{\circ} 1$.

Palavras-chave: Carica papaya L. Melhoramento genético. Mapa de preferência. Aceitação sensorial.

\section{Introduction}

Papaya (Carica papaya) is one of the most prominent fruit trees in tropical and subtropical areas of the world. Brazil is the second-largest producer worldwide, with nearly one million tons, which is equivalent to 927.1 million reais (Food and Agriculture Organization of The United Nations [FAO], 2019). The state of Bahia is the largest national producer (368.9 thousand tons) and, together with the state of Espírito Santo, accounted for $64 \%$ of the total country production in the 2017 harvest (Instituto Brasileiro de Geografia e Estatística [IBGE], 2017).

Brazilian papaya production is based only on a few cultivars. Papaya narrow genetic diversity, high incidence of pests, and climatic conditions compromise productivity and limit cropped area expansion (Dias, Oliveira, \& Dantas, 2011; Moretti, Mattos, Calbo, \& Sargent, 2010; Vivas et al., 2017). Commercially cultivated genotypes are the groups Solo and Formosa, which are distinguished by their fruit physical, physicochemical, and sensory characteristics.

The development of papaya cultivars with superior agronomic traits, disease resistance, and quality fruits that meet consumer demands is a major challenge for crop breeders, as these traits are rarely found in a single genotype (Vivas et al., 2017).

Physical aspects such as fruit appearance, size, and shape, as well as its nutritional characteristics, must be considered to satisfy national and international market requirements (Reis, Viana, Jesus, Dantas, \& Lucena, 2015). Papaya fruit quality is determined by its contents of sugars, organic acids, and minerals in the pulp, which vary according to cultivar, climate, crop treatment, production time, and harvest ripening stage (Souza, Coelho, Paz, \& Ledo, 2009). Papaya has a high nutritional value, being a source of vitamins A, B1, $\mathrm{B} 2$, and $\mathrm{C}$. It has a protein content of nearly $5 \%$ and its main carbohydrates are glucose, sucrose, and fructose, which are more abundant after ripening, when percentage of sugars varies between 10 and 13\% (Oliveira \& Vitória, 2011; Zhou \& Paull, 2001).

In addition to chemical and physical aspects, it is important to consider fruit sensory characteristics since product quality must also be defined as to consumers' perceptions. In this context, sensory tests are essential, in the final stage of development 
of a new cultivar so that fruits could present similar sensory characteristics to those of the groups Solo and Formosa.

Over the years, papaya breeding program of Embrapa Cassava and Fruticulture and partners have been testing different genotypes in search of new hybrids and lines with commercial potential. To choose the most promising genotypes, in addition to agronomic performance, fruit physicochemical and sensory characteristics must be assessed to support a decision on whether to launch a new cultivar in the market. Considering the above, the objective of this study was to evaluate papaya elite lines and hybrids as to their physicochemical and sensory characteristics, aiming to identify the most promising ones for insertion in the market.

\section{Material and Methods}

The experiment was carried out in Cruz das Almas-BA, Brazil (1240'39” S, 3906’22" W, and $226 \mathrm{~m}$ altitude), at an experimental area of Embrapa Cassava and Fruit Farming. Fruits from six improved genotypes and two cultivars (controls) were evaluated. The cultivars consisted of Golden (from Solo group) and Tainung $\mathrm{n}^{\circ} 1$ (from Formosa group). Solo-group improved genotypes were hybrid CMF H10.60 and line CMF L78, both developed by Embrapa Cassava and Fruticulture, and hybrid UC 14 developed by North Fluminense State University (UENF) and Caliman Agrícola SA company. Formosa-group improved genotypes were line CMF L10 (from Embrapa Cassava and Fruticulture) and the hybrids UC 10 and UC 12, also developed by UENF and Caliman Agrícola SA partnership.

The experimental design was carried out in randomized blocks, with five blocks for each genotype. Each experimental plot comprised eight plants, totaling 160 plants. Planting spacing consisted of $3.60 \mathrm{~m}$ between rows and $1.60 \mathrm{~m}$ between plants. Micro-irrigation was performed, and all recommended crop treatments were followed (Martins \& Costa, 2003).

Fruits were harvested at maturity stage 2 (up to $25 \%$ yellow peel) and evaluated at maturity stage 5 (fully yellow peel). Five fruits of each genotype and plot were evaluated for fruit length (FL, cm), fruit diameter (FD, cm), internal cavity diameter (ICD, $\mathrm{cm}$ ), fruit weight (FW, in $\mathrm{g}$ ), fruit firmness (FF, in $\mathrm{kgf} \mathrm{cm}^{-2}$ ), pulp firmness (PF, in $\mathrm{kgf} \mathrm{cm}^{-2}$ ), soluble solids ( $\mathrm{SS}$, in $\left.{ }^{\circ} \mathrm{Brix}\right), \mathrm{pH}$, and titratable acidity (TA, in $\%$ of citric acid). Firmness was determined using an analog penetrometer (McCormick model FT-32) coupled to an 8-mm-diameter tip, for ripe fruits with peel (FF) and without peel (PF). The content of SS was obtained with the aid of Hanna portable digital refractometer (model HI 96801). The $\mathrm{pH}$ was determined by direct reading of ripe fruit pulp in pH meter (Hanna brand, model pH 21). TA was analyzed by titration, determining grams of citric acid per $100 \mathrm{~g}$ of fruit. All physicochemical analyses were performed in triplicate and followed the procedures in the manual of the Instituto Adolfo Lutz [IAL, 2008].

The study was approved by the Research Ethics Committee of the Multidisciplinary Institute of Health of the Federal University of Bahia, registered under number 980.536. Sensory acceptance and purchase intention tests were performed on two different days, one for the genotypes of the Solo group and the other for those of Formosa group. Each test was performed in two stages, by 50 consumers, following the complete balance blocks design, with four treatments (genotypes of each group) and considering each consumer as a block.

In the first stage, the fruits were presented cut in half (transversely) for pulp appearance evaluation. After this, consumers had to inform purchase intention based only on fruit appearance. The second stage was performed inside individual cabin where consumers received fruit samples with sizes of $4.0 \times 2.5 \times 2.0 \mathrm{~cm}$, served monadically and sequentially. At this stage, consumers assessed 
overall acceptance, purchase intent (after tasting), and rated intensity of attributes: color (very light / very dark), aroma (weak / strong), taste (weak / strong), and texture in the mouth (too soft / too hard).

Acceptance test was performed using a ninepoint hedonic scale from 9 (extreme liking) to 1 (extreme disliking). For purchasing intention, a five-point scale was used, ranging from 5 (certainly would buy) to 1 (certainly would not buy). The intensity of papaya fruit attributes was measured by a nine-point intensity scale, as proposed by Meilgaard, Civille and Carr (2006).

Physical, physicochemical, and sensory data underwent univariate analysis of variance and Tukey test at 5\% probability. Sensory approval indices were calculated based on the sum of scores equal to or greater than 6 . Acceptance data were also subjected to a principal component analysis (PCA) from the covariance matrix, thus obtaining an internal preference mapping. Pearson's correlation coefficient between each sensory attribute (intensity scale) and the principal components was calculated, thus designing a map with products, consumers, and attributes. Statistical analyses were performed with the aid of the R statistical software (R Core Team [R], 2018).

\section{Results and Discussion}

The coefficients of experimental variation ranged from $0.77 \%$ to $50.94 \%$ for $\mathrm{pH}$ and pulp firmness, respectively (Table 1). The highest coefficients were observed for pulp firmness and fruit firmness, with values of $22.51 \%$ and $50.94 \%$ for the Solo group and $21.52 \%$ and $29.53 \%$ for the Formosa group, respectively. The high coefficients of variation of these characteristics may be due to variations among fruits from the same genotype. Reis et al. (2015) also observed high coefficients for fruit firmness (27.70\%) and pulp firmness (40.54\%), corroborating the findings of Oliveira, Lima, Lucena, Motta and Dantas (2010), who reported a coefficient of variation of $23.88 \%$, when assessing fruit firmness.

\section{Table 1}

Physicochemical properties of papaya elite hybrids and lines of Solo and Formosa groups*

\begin{tabular}{|c|c|c|c|c|c|c|c|c|c|c|}
\hline \multirow{2}{*}{ Genotype } & \multicolumn{10}{|c|}{ Solo Group } \\
\hline & FL & FD & $\mathrm{FW}$ & ICD & $\mathrm{FF}$ & $\mathrm{PF}$ & $\mathrm{SS}$ & $\mathrm{pH}$ & TA & Ratio \\
\hline CMF H10.60 & $13.50 \mathrm{bc}$ & $8.84 a$ & $487.64 \mathrm{ab}$ & $4.67 \mathrm{a}$ & $2.23 b$ & $0.62 b$ & $14.55 \mathrm{a}$ & $5.16 \mathrm{bc}$ & $0.07 \mathrm{~b}$ & $213.52 \mathrm{ab}$ \\
\hline CMF L78 & $14.36 \mathrm{~b}$ & $8.96 \mathrm{a}$ & $555.56 \mathrm{a}$ & $5.38 \mathrm{a}$ & $3.01 \mathrm{ab}$ & $1.19 \mathrm{ab}$ & $13.94 \mathrm{a}$ & $5.22 b$ & $0.06 \mathrm{~b}$ & $224.16 \mathrm{a}$ \\
\hline UC 14 & $16.28 \mathrm{a}$ & $8.84 \mathrm{a}$ & $633.32 \mathrm{a}$ & $5.07 \mathrm{a}$ & $3.93 \mathrm{a}$ & $2.03 \mathrm{a}$ & $14.36 \mathrm{a}$ & $5.12 \mathrm{c}$ & $0.08 \mathrm{a}$ & $173.78 b$ \\
\hline Golden & $12.04 \mathrm{c}$ & $7.66 \mathrm{~b}$ & $346.48 b$ & $4.59 \mathrm{a}$ & $3.66 \mathrm{a}$ & $1.34 \mathrm{ab}$ & $12.72 b$ & $5.32 \mathrm{a}$ & $0.06 \mathrm{~b}$ & $196.59 \mathrm{ab}$ \\
\hline Mean & 14.04 & 8.58 & 505.75 & 4.93 & 3.21 & 1.29 & 13.89 & 5.21 & 0.07 & 202.01 \\
\hline CV (\%) & 5.95 & 6.04 & 17.46 & 9.7 & 22.61 & 50.94 & 4.57 & 0.77 & 10.78 & 10.52 \\
\hline \multirow{2}{*}{ Genotype } & \multicolumn{10}{|c|}{ Formosa Group } \\
\hline & FL & FD & FW & $\mathrm{ICD}$ & FF & $\mathrm{PF}$ & SS & $\mathrm{pH}$ & TA & Ratio \\
\hline CMF L10 & $21.84 b$ & $9.75 c$ & $947.24 \mathrm{c}$ & $5.17 \mathrm{~b}$ & $3.12 \mathrm{a}$ & $1.61 \mathrm{a}$ & $11.51 b$ & $5.20 \mathrm{a}$ & $0.07 \mathrm{a}$ & $162.97 \mathrm{a}$ \\
\hline UC 10 & $26.90 \mathrm{a}$ & $11.87 \mathrm{a}$ & $1834.00 \mathrm{a}$ & $6.35 \mathrm{a}$ & $3.42 \mathrm{a}$ & $1.73 a$ & $12.96 \mathrm{a}$ & $5.28 \mathrm{a}$ & $0.08 \mathrm{a}$ & $166.05 \mathrm{a}$ \\
\hline UC 12 & $21.56 \mathrm{~b}$ & $10.46 \mathrm{bc}$ & $1147.76 \mathrm{bc}$ & $5.67 b$ & $3.23 \mathrm{a}$ & $1.28 \mathrm{a}$ & $13.50 \mathrm{a}$ & $5.29 \mathrm{a}$ & $0.07 \mathrm{a}$ & $182.53 a$ \\
\hline Tainung $\mathrm{n}^{\circ} 1$ & $25.92 \mathrm{a}$ & $10.70 \mathrm{c}$ & $1333.44 b$ & $5.69 \mathrm{~b}$ & $3.67 \mathrm{a}$ & $1.91 \mathrm{a}$ & $12.70 \mathrm{a}$ & $5.15 \mathrm{a}$ & $0.07 \mathrm{a}$ & $179.91 \mathrm{a}$ \\
\hline Mean & 24.05 & 10.69 & 1315.61 & 5.72 & $3.36^{\mathrm{s}}$ & 1.63 & 12.67 & 5.23 & 0.07 & 172.86 \\
\hline CV (\%) & 6.53 & 4.12 & 10.88 & 5.51 & 21.52 & 29.53 & 4.56 & 2.49 & 10.79 & 14.22 \\
\hline
\end{tabular}

* Means (in triplicates) followed by the same letters in columns do not differ from each other by the Tukey's test at $5 \%$ probability. FL: fruit length $(\mathrm{cm})$; FD: fruit diameter $(\mathrm{cm})$; FW: fruit weight $(\mathrm{g})$; ICD: internal cavity diameter $(\mathrm{cm})$; FF: fruit firmness $\left(\mathrm{kg} \mathrm{cm}^{-}\right.$

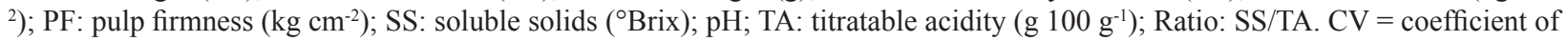
experimental variation. 
Significant differences were observed among the genotypes of the Solo group for all physical and physicochemical characteristics, except for internal cavity diameter (ICD), with a mean value of 4.93 $\mathrm{cm}$ (Table 1). Regarding physical dimensions, UC 14 produced the longest fruits $(16.28 \mathrm{~cm})$, while the control Golden and the hybrid CMF H10.60 presented the lowest mean for this variable (Table 1). The genotypes CMF L78 and UC 14 presented fruits with larger diameter and weight when compared to the fruits of cultivar Golden. This lower performance expressed by the cultivar Golden should be related to the fact that this cultivar has been cultivated for many years and has shown degeneration in its characteristics (Luz, Pereira, Barros, Barros, \& Ferreguetti, 2015; Pinto, Ramos, Cardoso, Luz, \& Pereira, 2013). However, all evaluated genotypes presented values of fruit weight (FW) within the range defined for Solo group, which is between 300 $\mathrm{g}$ and $650 \mathrm{~g}$ (Dias et al., 2011).

Firmness is one of the most relevant quality attributes since less firm fruits have lower resistance to transport, storage, and handling (Fagundes \& Yamanishi, 2001), and hence shorter shelf life. The fruits of genotypes CMF L78 and UC 14 showed fruit firmness (FF) of $3.01 \mathrm{~kg} \mathrm{~cm}^{-2}$ and $3.93 \mathrm{~kg} \mathrm{~cm}^{-2}$, and pulp firmness (PF) of $1.19 \mathrm{~kg} \mathrm{~cm}^{-2}$ and $2.03 \mathrm{~kg}$ $\mathrm{cm}^{-2}$ (Table 1), respectively, being similar to Golden cultivar fruits $\left(\mathrm{FF}=3.63 \mathrm{~kg} \mathrm{~cm}^{-2}\right.$ and $\mathrm{PF}=1.34 \mathrm{~kg}$ $\mathrm{cm}^{-2}$ ).

The content of soluble solids (SS) is another important quality attribute in papaya fruits. For exportation, fruits are required to have a content of SS above $12^{\circ}$ Brix, while breeding programs seek genotypes with SS content above $14{ }^{\circ}$ Brix (Dantas, Dantas, \& Lima, 2002; Dantas, Lucena, \& Vilas Boas, 2015). Fruits from the three improved genotypes did not differ in SS content, and presented an average of $14.3{ }^{\circ}$ Brix (Table 1), surpassing the commercial cultivar Golden. Viana, Reis, Silva, Neves and Jesus (2015) reported greater variation in SS contents for genotypes of Solo group (11.15 to $15.10^{\circ}$ Brix) compared to our findings. On the other hand, Dantas et al. (2015) obtained a $12.9^{\circ}$ Brix as the highest SS content for hybrids and lines of the Solo group.

Significant differences were observed for $\mathrm{pH}$ and titratable acidity (TA). The genotype UC 14 had lower $\mathrm{pH}$ (5.12) and higher TA $\left(0.008 \mathrm{~g} 100 \mathrm{~g}^{-1}\right.$ citric acid) (Table 1). The genotypes CMF H10.60, CMF L78, and Golden (control) did not differ in relation to the Ratio (SS/TA), while UC 14 genotype had the lowest value. This Ratio is an important variable, and usually, fruits with a higher Ratio have a greater perception of fruit sweetness by consumers, which may lead to a greater acceptance (Reis et al., 2015).

For the genotypes of Formosa group (Table 1), the hybrid UC10 presented fruit length (FL) equal to that of the cultivar Tainung $n^{\circ} 1$, besides higher means for fruit diameter - FD $(11.87 \mathrm{~cm})$, fruit weight - FW (1834.00g), and internal cavity diameter - ICD $(6.35 \mathrm{~cm})$. When evaluating genotypes of Formosa Group, Barros, Kuhlcamp, Arantes and Moreira (2017) found a variation of 945.22 to $2,202.82 \mathrm{~g}$ for FW, demonstrating a greater amplitude than that observed in this study. For selection and classification of new papaya genotypes, FW is an important feature. In addition to that, fruit shape should be considered to facilitate packaging and transportation processes (Dantas et al., 2015).

Regarding SS content, the hybrids UC 10 and UC 12, and the control Tainung $\mathrm{n}^{\circ} 1$ were superior to CMF L10. Reis et al. (2015) reported a similar result for SS in hybrids and papaya lines of the Formosa group, presenting values between 12.49 and $14.76^{\circ}$ Brix. In contrast, Luz et al. (2015), when evaluating elite papaya genotypes, found a variation of 8.87 to $11.17{ }^{\circ}$ Brix in SS content for UC 10 and UC 12 hybrids grown in the states of Espírito Santo and Rio Grande do Norte (in Brazil).

For FF, PF, pH, TA, and Ratio (Table 1), the improved genotypes of Formosa group did not differ from each other, presenting similar characteristics to the commercial cultivar Tainung $n^{0} 1$, which demonstrates the potential of these genotypes for market insertion. 
Changes in physical and physicochemical characteristics of papaya fruits may be due to a genotype-environment interaction, which justifies the differences observed in this study and those obtained by other authors.

Table 2 shows the sensory evaluation results for the new genotypes. For the internal appearance of fruits from Solo group, CMF L78 and UC 14 did not differ from the control Golden, and consumers gave scores above 7.0 , being thus classified into "liked moderately" and "liked very much ". The approval percentage for these three genotypes was over 94\%. However, in considering purchase intention, both CMF L78 and UC 14 surpassed the commercial cultivar Golden, with values of 88 and $82 \%$, respectively, demonstrating that these materials have excellent market potential. The hybrid CMF H10.60 was the one with the lowest average acceptance of the internal appearance, as well as the lowest purchase intention.

Table 2

Acceptance, approval percentage, and purchase intention of papaya fruits from genotypes of Solo and Formosa groups*

\begin{tabular}{ccccccc}
\hline \multirow{2}{*}{ Genotype } & \multicolumn{3}{c}{ Internal Appearance } & \multicolumn{3}{c}{ Global Acceptance } \\
\cline { 2 - 7 } & Average $^{1}$ & AP (\%) & PI (\%) & Mean $^{1}$ & AP (\%) & IC (\%) \\
\hline CMF H10.60 & $6.28 \mathrm{c}$ & 80.00 & 44.00 & $7.24 \mathrm{a}$ & 92.00 & 76.00 \\
CMF L78 & $7.84 \mathrm{a}$ & 96.00 & 88.00 & $7.26 \mathrm{a}$ & 94.00 & 72.00 \\
UC 14 & $7.52 \mathrm{ab}$ & 94.00 & 82.00 & $7.12 \mathrm{ab}$ & 90.00 & 76.00 \\
Golden & $7.16 \mathrm{~b}$ & 96.00 & 66.00 & $6.58 \mathrm{~b}$ & 86.00 & 48.00 \\
\hline Mean & 7.20 & - & - & 7.05 & - & - \\
CV (\%) & 17.54 & - & - & 15.51 & - & - \\
\hline \multirow{2}{*}{ Genotype } & \multicolumn{7}{c}{ Internal Appearance } & & Global Acceptance \\
\cline { 2 - 7 } CMF L10 & Average & AP (\%) & PI (\%) & Mean ${ }^{1}$ & AP (\%) & IC (\%) \\
UC 10 & $4.81 \mathrm{c}$ & 46.15 & 11.54 & $5.13 \mathrm{c}$ & 57.69 & 14.00 \\
UC 12 & $6.79 \mathrm{~b}$ & 92.31 & 53.85 & $7.60 \mathrm{a}$ & 96.15 & 88.00 \\
Tainung n ${ }^{\circ} 1$ & $6.96 \mathrm{~b}$ & 90.38 & 71.15 & $6.42 \mathrm{~b}$ & 80.77 & 50.00 \\
\hline Mean & $8.27 \mathrm{a}$ & 98.08 & 96.15 & $6.94 \mathrm{ab}$ & 86.54 & 58.00 \\
CV (\%) & 6.71 & - & - & 6.52 & - & - \\
\hline
\end{tabular}

* Means followed by the same letters in columns do not differ from each other by the Tukey's test at $5 \%$ probability. ${ }^{1}$ Mean hedonic scores (50 consumers) according to a nine-point scale. AP = approval percentage (scores equal to and above 6.0). PI $=$ purchase intention considering the hedonic terms "probably would buy" and "certainly would buy". CV = coefficient of experimental variation.

The approval percentage of CMF H10.60 fruits increased after tasting, which shows that consumers liked the pulp of this genotype. The fruits of the genotypes CMF H10.60, L78, and UC 14 did not differ from each other and presented the highest global acceptance averages, with approval rates above $90 \%$ and purchase intention over $72 \%$ (Table 2 ). The commercial cultivar Golden presented the lowest percentage of approval (86\%) and purchase intention (48\%). This result confirms that the new genotypes of Solo group have a highly competitive capacity against the existing cultivars in the market.

Regarding the sensory acceptance of the internal appearance of fruits from Formosa group genotypes (Table 2), Tainung $\mathrm{n}^{\mathrm{o}} 1$ (control) was the most accepted cultivar, with high percentages of approval (98.08\%) and purchase intention $(96.15 \%)$, being superior to the others. The hybrids UC 10 and UC 12 performed better among the new genotypes 
evaluated, with internal appearance approval above $90 \%$. The line CMF L10 was the one that presented the lowest acceptance, being classified between the hedonic terms "disliked slightly" and "not liked or not disliked", as well as lower approval percentage and purchase intention. This line also presented the lowest approval percentage (46.15\%) and purchase intention (11.54\%), which clearly indicates that consumers did not like the internal appearance of these fruits.

After tasting, the genotype UC10 surpassed the cultivar Tainung $\mathrm{n}^{\mathrm{o}} 1$ in terms of approval percentage (96.15\%) and purchase intention (88\%).

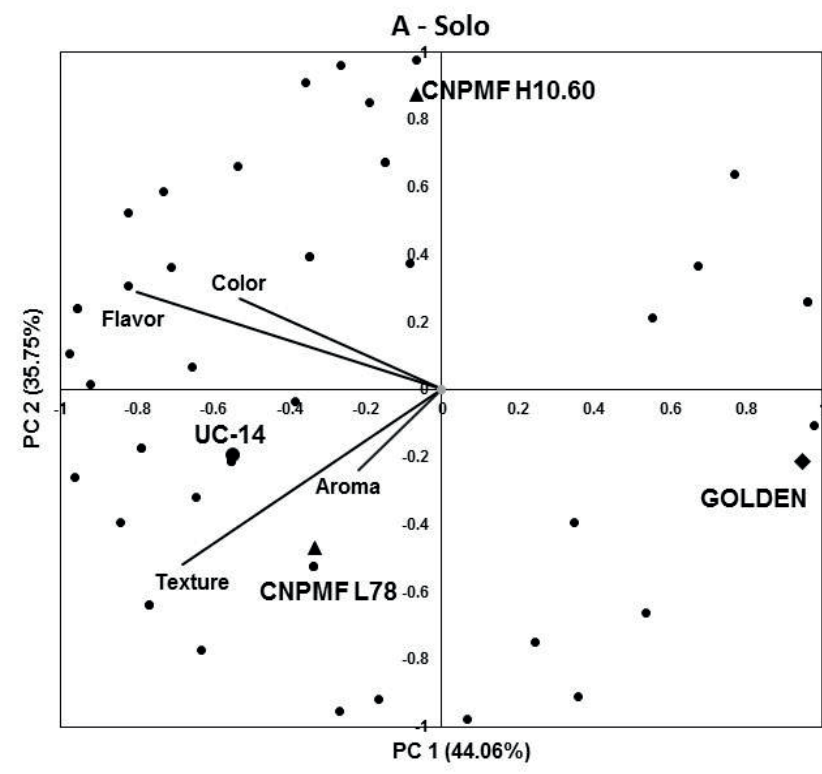

Figure 1. Internal preference mapping for papaya fruits from genotypes of Solo (A) and Formosa (B) groups.

For the genotypes of the Solo group (Figure 1A), the first principal component (PC1) explained $44.06 \%$ of the total variance and the second one (PC2) explained 35.75\%. Both components explained $79.81 \%$ of the total variance of papaya genotype acceptance. The spatial separation of genotypes suggests the existence of three groups of acceptance, the first formed by CMF L78 and UC 14, the second by CMF H10.60, and the third by Golden. Most of the consumers are in the second and third quadrants of the map, indicating their preference for



To examine individual consumer preferences, global acceptance data (after tasting) were subjected to principal component analysis to obtain an internal preference mapping for each genotype group (Figure 1). The positioning of each genotype in this map shows the difference among them in terms of acceptance by consumers. The vectors represent the Pearson correlations of the sensory attributes (intensity scale) and the two principal components; therefore, it is possible to infer which sensory characteristics contribute to fruit preference. 
flavor, and firmer texture than the others. In short, consumers tend to prefer fruits presenting such attributes in greater intensities. The cultivar Golden, located to the right side of the map, was considered to have a weaker taste, lighter color, and softer texture, which may justify its lower acceptance by consumers.

Figure 1B represents the internal preference mapping for the four genotypes of the Formosa group. The two principal components explained $82.2 \%$ of the total variation for acceptance data. It should be noted that most of the consumers are located to the left of the map, i.e. preferring UC 10 and Tainung $\mathrm{n}^{\circ}$ 1. Aroma, color, and flavor are attributes that grow toward these genotypes, indicating that consumers considered the most intense aroma, color and flavor in the pulp of these genotypes. However, texture grows in the opposite direction, showing that these genotypes presented softer pulps than did the others. It can be inferred that the preferred genotypes of Formosa group presented the most intense pulp color, stronger aroma and taste, and softer texture. The genotype CMF L10, which is in the first quadrant, was the least accepted, and its pulp was characterized by lighter color, weaker taste and aroma, and firmer texture.

\section{Conclusion}

The line CMF L78 of Solo group and the hybrid UC10 of Formosa group showed similar fruit firmness and Ratio to those of the commercial cultivars Golden and Tainung $\mathrm{n}^{\mathrm{o}}$ 1. However, these improved genotypes surpassed the cultivars (controls) in terms of sensory acceptance, being promising alternatives for the consumer market for papaya.

\section{References}

Barros, F. L. S., Kuhlcamp, K. T., Arantes, S. D., \& Moreira, S. O. (2017). Productivity and quality of
Formosa and Solo papaya over two harvest seasons. Pesquisa Agropecuária Brasileira, 52 (8), 599-606. doi: 10.1590/S0100-204X2017000800005

Dantas, J. L. L., Dantas, A. C. V. L., \& Lima, J. F. de. (2002). Mamoeiro. In C. H. Bruckner (Ed.), Melhoramento de fruteiras tropicais (pp. 309-349). Viçosa, MG: UFV.

Dantas, J. L. L., Lucena, R. S., \& Vilas Boas, S. A. (2015). Avaliação agronômica de linhagens e híbridos de mamoeiro. Revista Brasileira de Fruticultura, 37(1), 138-148. doi: 10.1590/0100-2945-022/14

Dias, N. L. P., Oliveira, E. J. de, \& Dantas, J. L. L. (2011). Avaliação de genótipos de mamoeiro com uso de descritores agronômicos e estimação de parâmetros genéticos. Pesquisa Agropecuária Brasileira, 46 (11), 1471-1479. doi: 10.1590/S0100204X2011001100008

Fagundes, G. R., \& Yamanishi, O. K. (2001). Características físicas e químicas de frutos de mamoeiro do grupo Solo comercializados em quatro estabelecimentos de Brasília, DF. Revista Brasileira de Fruticultura, 23 (3), 541-5451. doi: 10.1590/ S0100-29452001000300018

Food and Agriculture Organization of The United Nations. (2019). The agricultural production. Retrieved from http://www.fao.org/faostat/en/\#data/ QC/visualize.

Instituto Adolfo Lutz. (2008). Métodos físico-químicos para análise de alimentos. São Paulo, SP: IAL. 1020 p.

Instituto Brasileiro de Geografia e Estatística. (2017). Produção agrícola municipal. Retrieved from https:// sidra.ibge.gov.br/tabela/5457\#resultado

Luz, L. N. da, Pereira, M. G., Barros, F. R., Barros, G. de B., \& Ferreguetti, G. A. (2015). Novos híbridos de mamoeiro avaliados nas condições de cultivo tradicional e no semiárido brasileiro. Revista Brasileira de Fruticultura, 37(1), 159-171. doi: 10.1590/0100-2945-069/14

Martins, D. S., \& Costa, A. de F. S. da. (2003). A cultura do mamoeiro: tecnologias de produção. Vitória, ES: INCAPER. 497 p.

Meilgaard, M., Civille, G. V., \& Carr, B. T. (2006). Sensory evaluation techniques. (4nd ed.). Boca Raton: CRC Press. 464 p.

Moretti, C. L., Mattos, L. M., Calbo, A. G., \& Sargent, S. A. (2010). Climate changes and potential impacts on postharvest quality of fruit and vegetable crops: a review. Food Research International, 43(7), 18241832. doi: $10.1016 /$ j.foodres.2009.10.013 
Oliveira, E. J., Lima, D. S., Lucena, R. S, Motta, T. B. N., \& Dantas, J. L. L. (2010). Correlações genéticas e análise de trilha para número de frutos comerciais por planta em mamoeiro. Pesquisa Agropecuária Brasileira, 45(8), 855-862. doi: 10.1590/S0100204X2010000800011

Oliveira, J. G., \& Vitoria, A. P. (2011). Papaya: nutritional and pharmacological characterization, and quality loss due to physiological disorders. An overview. Food Research International, 44(5), 1306-1313. doi: 10.1016/j.foodres.2010.12.035

Pinto, F. O., Ramos, H. C. C., Cardoso, D. L., Luz, L. N., \& Pereira, M. G. (2013). Desenvolvimento de genótipos tolerantes à mancha fisiológica. Revista Brasileira de Fruticultura, 35(4), 1101-1115. doi: 10.1590/S0100-29452013000400022.

R Core Team. (2018). R: A language and environment for statistical computing. Vienna: R Foundation for Statistical Computing. Retrieved from http:// www.R-project.org

Reis, R. C., Viana, E. S., Jesus, J. L., Dantas, J. L. L., \& Lucena, R. S. (2015). Caracterização físico-química de frutos de novos híbridos e linhagens de mamoeiro. Pesquisa Agropecuária Brasileira, 50(3), 210-217. doi: 10.1590/S0100-204X2015000300004
Souza, T. V., Coelho, E. F., Paz, V. P. S, \& Ledo, C. A. S. (2009). Avaliação física e química de frutos de mamoeiro Tainung $\mathrm{n}^{\mathrm{o}} 1$, fertirrigado com diferentes combinações de fontes nitrogenadas. Revista Brasileira de Ciências Agrárias, 4(2), 179-184. doi: 10.5039/agraria.v4i2a10

Viana, E. S., Reis, R. C., Silva, S. C. S., Neves, T. T., \& Jesus, J. L. (2015). Avaliação físico-química e sensorial de frutos de genótipos melhorados de mamoeiro. Pesquisa Agropecuária Tropical, 45(3), 297-303. doi: 10.1590/1983-40632015v4535008

Vivas, M., Silveira, S. F., Vivas, J. M. S., Santos, P. H. D., Carvalho, B. M., Daher, R. F,... Pereira, M. G. (2017). Phenotypic characterization of papaya genotypes to determine powdery mildew resistance. Crop Breeding and Applied Biotechnology, 17(3), 198-205. doi: 10.1590/1984-70332017v17n3a31

Zhou, L., \& Paull, R. E. (2001). Sucrose metabolismo during papaya (Carica papaya) fruit growth and ripening. Journal of the American Society for Horticultural Science, 126(3), 351-357. doi: 10.21273/JASHS.126.3.351 
